\title{
Hepatotoxic Effects of the Methanol Extract of Senna Siemea in Wister Rats
}

\author{
James G0, Omeje KO, David EA, Eze SOO* and Uzoegwu PN \\ Department of Biochemistry, , Nigeria \\ *Corresponding author: Eze SOO, Department of Biochemistry, Enugu State, Nigeria
}

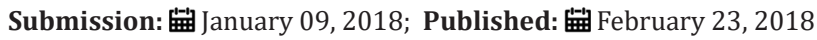

\begin{abstract}
Senna siamea is a plant used in the tradomedicinal practice for the treatment of malaria. Despite its efficacy, there is no scientific information concerning the safety of the plant extract on the liver hence, the study evaluated the effect of the methanol extract on liver function enzymes in wistar albino rats. Thirty two rats weighing between $180-210 \mathrm{~g}$ were randomly grouped into four of 8 rats each. Group 1 (control group) received normal saline, while groups 2, 3 and 4 received orally 100,200 and $400 \mathrm{mg} / \mathrm{kg} / \mathrm{body}$ weight of the extract. Two animals were sacrificed on weeks 1,2, 3 and 4 respectively and both blood and organ samples were collected. Results showed 4.4\% percentage yield of MESS which contains a range of phytochemicals. The liver marker enzymes AST and ALP showed no significant changes in their serum activity while ALT activity increased significantly ( $p<0.05)$ during the 3rd and 4th weeks. Bilirubin concentration also increased significantly $(\mathrm{p}<0.05)$ during the 3rd and 4th week of administration of the extract to the 4 th group. This investigation suggests that prolonged ingestion of high concentration of methanol extract of $S$. siamea (MESS) could be toxic to hepatocytes. This was further revealed by the histological examination result showing degenerative changes when compared to the control.
\end{abstract}

Keywords: Methanol extract; Liver; Hepatotoxicity; Wistar rat; Senna siamea

\section{Introduction}

The use of medicinal plant is presently on the increase due to its availability, affordability, accessibility, and promising efficacy comparable to the often high cost and adverse effects associated with standard synthetic drugs [1]. However, people are often unaware of important similarities and differences between medicinal herbs and approved medications. Some mistakenly think of herbs as natural alternatives to chemicals, failing to recognize that herbs are composed of bioactive chemicals some of which may be toxic [2]. Toxicity studies on medicinal plants or extracts usually determine the level of safety particularly during the development of drugs [3].

Senna siamea also called Cassia siamea is an angiosperm native of Southeast Asia and widely distributed in Africa, Latin America and in Oceania. The leaves, stems, roots, flowers and seeds of $S$. siamea regardless the subspecies, have been used for the treatment of several ailments including malaria [4]. According to the ethnic differences of populations from localities, the plant is used alone or in combination with other plants or with natural substances for the preparation especially in decoction [5,6]. The leaves are the most used part of the plant especially by African and Asian populations in preparation of the herbal remedies (REF). In Nigeria, the dried leaves are mixed with lemon leaves (Cymbopogon citratus), pawpaw leaves (Carica papaya), and the lime leaves (Citrus lemonum) and are boiled within an hour. The "tea" of the mixture is drunk against malaria [7]. One therefore expects bioactive compounds obtained from such plants to have low animal and human toxicity on organs such as the liver.

It is the most common site of damage in laboratory animals administered with drugs and other chemicals [8]. Although chemicals are delivered to the liver for metabolism and excretion, this can frequently lead to liver injury [9], when performing its functions of biotransformation of xenobiotics, endogenous compounds, including hormones carbohydrate metabolism and storage synthesis of blood proteins (albumin, lipoproteins) urea formation, fat metabolism and bile formation [8]. Hence, the aim of this study is to evaluate the effect of the methanol extract of the leaf of Senna siamea on liver function indices in wistar rat.

\section{Methods}

\section{Plant collection and identification}

The leaves of Senna siamea was collected from Idah, Idah Local Government Area of Kogi state and identified in the Herbarium of the Department of Plant Science and Biotechnology, University of Nigeria, Nsukka, Enugu State. The plant leaves were then air dried and pulverized. 


\section{Preparation of plant material}

A quantity $(500 \mathrm{~g})$ of the powdered leaves of Senna siamea was extracted by maceration in 1.8L of $98 \%$ methanol for $48 \mathrm{hr}$. This was filtered with mesh, followed by Whatman no 1 filter paper and the filtrate concentrated using rotary evaporator at $40^{\circ} \mathrm{C}$. The Percentage yield of the methanol extract of S. siamea was calculated.

Preparation of the animal samples and experimental design: Thirty two adult wistar albino rats $(180-210 \mathrm{~g})$ were obtained from the Animal house of the Department of Zoology and Environmental Biology, University of Nigeria, Nsukka. They were fed in the animal house with commercial rat chow (Top feed grower's mash).

The animals were divided into four groups of eight rats each. They received the methanol extract orally once every $24 \mathrm{hr}$, for the period of twenty nine days as follows:

Group 1 =Received normal saline (control)

Group $2=$ Fed $100 \mathrm{mg} / \mathrm{kg}$ b.w of methanol extract of $S$. siamea (MESS)

Group $3=$ Fed $200 \mathrm{mg} / \mathrm{kg}$ b.w of methanol extract of $S$. siamea (MESS)

\section{Group $4=$ Fed $400 \mathrm{mg} / \mathrm{kg}$ b.w of methanol extract of S. siamea}

The extract was administered orally. Two rats from each group were taken and sacrificed on the 1,2, 3 and 4 weeks respectively for the biochemical tests. Also, on the 4 week, the liver and kidney were collected for histopathological studies.

\section{Sample collection}

The blood sample was collected through cardiac puncture. The blood sample was kept at room temperature for $30 \mathrm{~min}$ thereafter; it was centrifuged at $3000 \mathrm{rpm}$ for ten minutes using a table centrifuge, to enable a complete separation of the serum from the clotted blood. The clear serum supernatant was then carefully vaspirated with syringe and needle and stored in a clean sample bottle for the clinical chemistry determinations.

Assay of alanine aminotransferase (ALT) activity: Alanine aminotransferase activity was determined by the [10] colorimetric method for in vitro determination.

Assay of serum alkaline phosphatase (ALP) activity: Serum alkaline phosphatase activity was determined using Phenolphthalein monophosphate method of [11].

Assay of aspartate aminotransferase (AST) activity: Aspartate aminotransferase (AST) activity was determined according to Park et al. [12]. The concentration of conjugated and unconjugated bilirubin was determined using the method of Caio et al. [13]. The histopathological examination of the tissues of the liver and kidney of Wistar rats was done using the method of Drury et al. [14].

\section{Statistical Analysis}

The data obtained were analyzed using IBM Statistical Package for Service Solutions (SPSS) version 16.0 and the results expressed as mean \pm standard deviation of mean. Significant differences of the result were established by one-way ANOVA and the acceptance level of significance was $\mathrm{p}<0.05$ for all the results.

\section{Results}

A percentage yield of $4.4 \%$ was recorded for the methanol extract from Senna siamea. The effects of methanol leaf extract of Senna siamea on the activities of liver function enzymes (AST, ALT, ALP) in rats administered with 100,200 and $400 \mathrm{mg} / \mathrm{kg}$ body weight of the extract are shown in Figure 1-3 respectively. Similarly, Figure 4 shows the total bilirubin concentrations of the rat. Plate 1 shows the histopathologic picture of the liver in group 1 (control) showing the normal liver architecture with intact hepatocytes, sinosoids and kuffer cells.

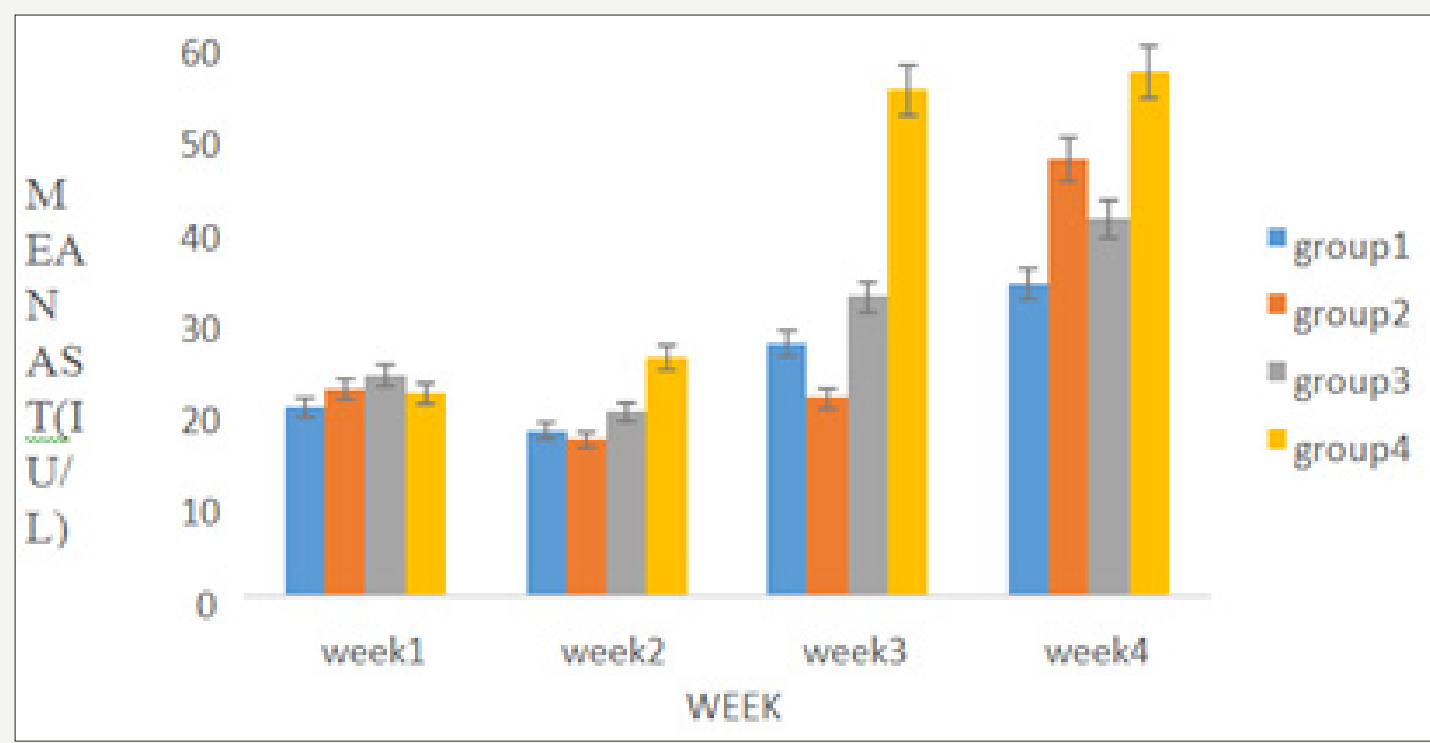

Figure 1: Showing the effect of methanol extract of Senna siamea leaf on Aspartate aminotransferase activity. 


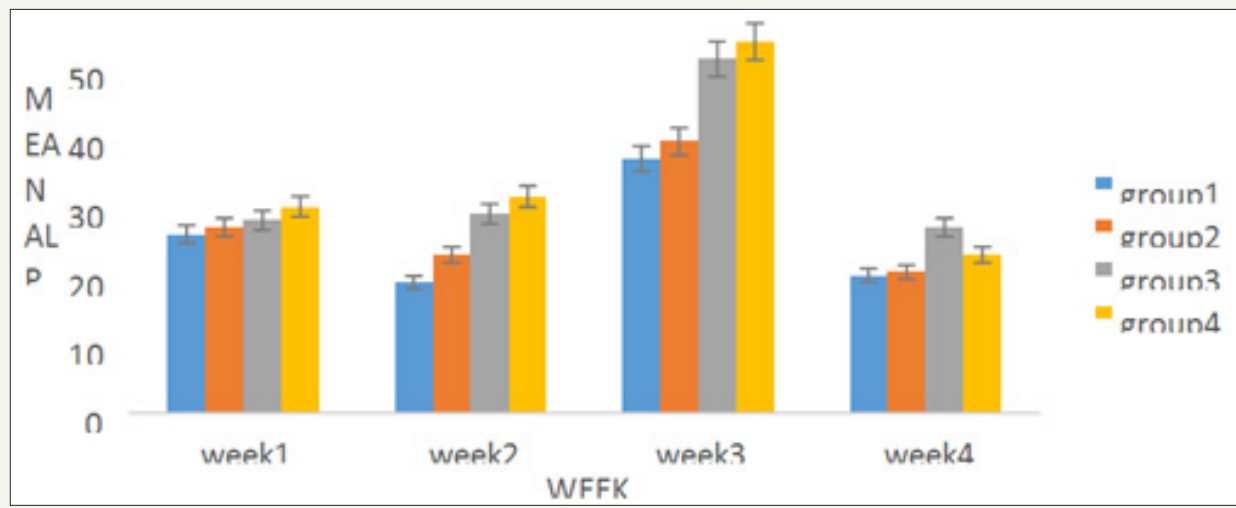

Figure 2: Showing the effect of methanol extract of Senna siamea leaves on Alkaline phosphatase activity.

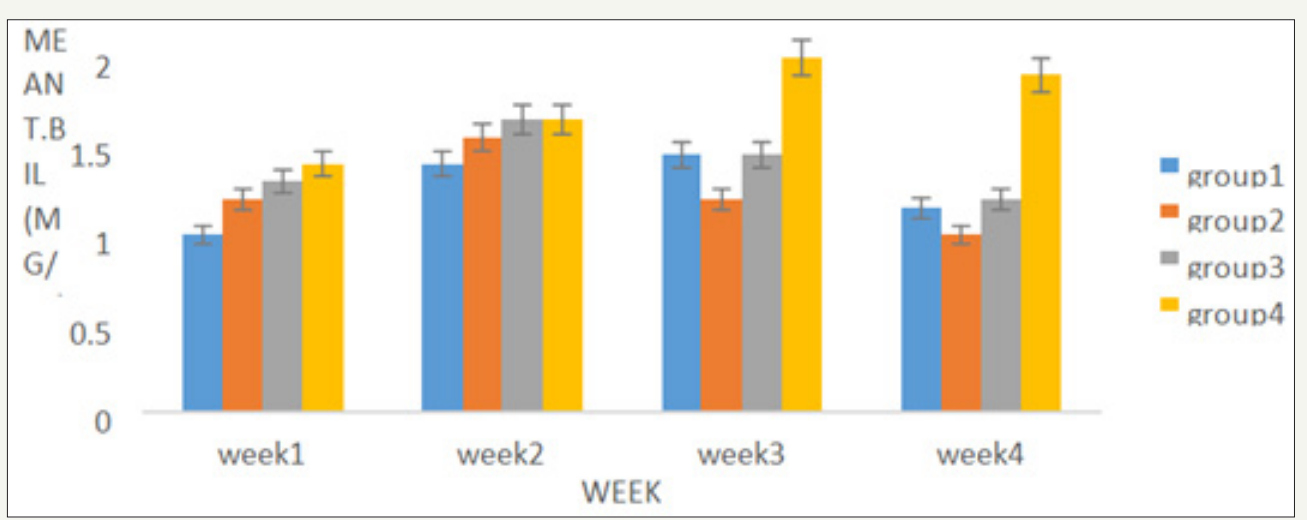

Figure 3: Showing the effect of methanol extract of Senna siamea leaf on Total Bilirubin concentration in Wistar rats.

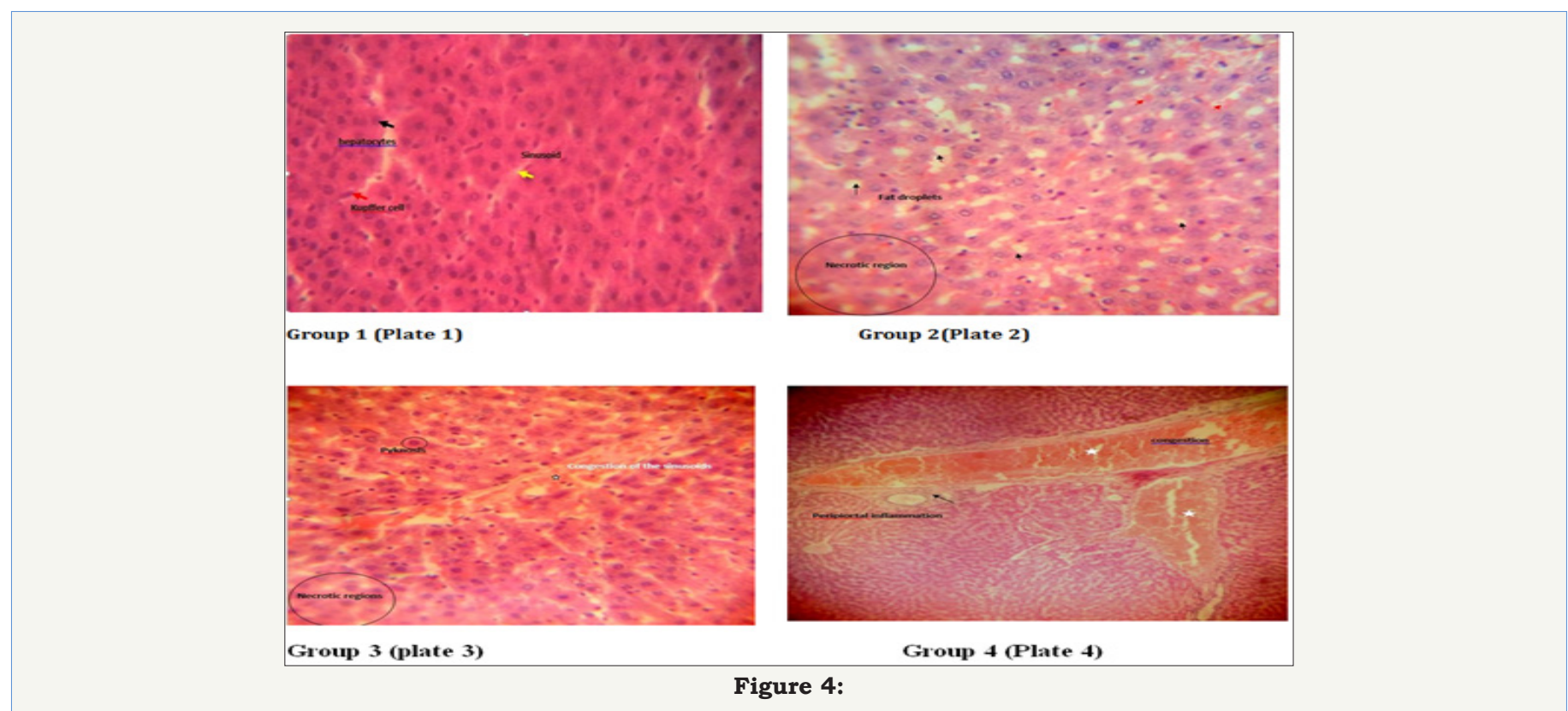

In plate 2 (Group 2), steatosis was observed. Also, Plate 2 and 3 showed necrotic regions in the liver cells of group 2 and 3 respectively. Plate 3 showed proliferation and hyperplasia of the bile ducts around the central vein in wistar rats. Periportal inflammation and congestion was also observed in group 4 of plate 4 when compared to the control.

\section{Discussion}

There was no significant $(\mathrm{p}>0.05)$ difference observed in the activities of liver marker enzymes AST and ALP as shown in the figures. But, a significant $(\mathrm{p}<0.05)$ difference was observed in the ALT activities in weeks 3 and 4 . ALT is used to identify liver damage arising from liver cell inflammation or necrosis [15]. It is more 
specific to liver and thus a better parameter for detecting liver injury since AST is also associated with diseases in other organ such as heart and muscle [16]. Increased activity of ALT may be as a result of inflammatory condition of the liver, scarring, death of liver tissue. In plate 2 (Group 2), steatosis was observed. This is a type of liver injury that may manifest as a result of triacylglycerol accumulation [17] leading to small droplet (microvascular) of fats. Necrosis is a form of cell injury which results in the premature death of cells in living tissue by autolysis [18]. It is caused by factors external to the cell or tissue, such as infection, toxins, or trauma which result in the unregulated digestion of cell components [19]. Necrosis of hepatocytes observed in the wistar rat was in accord with Mohammed et al. [20] who reported that barakol caused dose dependent degeneration and necrosis of hepatocytes in rat. Periportal inflammation and congestion which was also observed in group 4 of plate 4 when compared to the control could lead to liver dysfunction due to venous congestion as noted by Cosmas and Giallourakis, [21].

\section{Conclusion}

Senna siamea is efficacious and tolerated in short term treatment of malaria, but caution should be taken when using the extract for long term therapy, it has observed prolonged administration of the extract for up to 28 days may cause damage to the liver.

\section{Acknowledgement}

The authors wish to thank Eze Fransisca 0. of Dean's office, Faculty of Biological Sciences for typing this manuscript.

\section{References}

1. Sulaiman SR, Ali AJ, Mohammed TA (2015) In vitro antiplasmodial and effects of sub-chronic administration of Trichilia emetic leaves extracts. International Research Journal of Natural Sciences 3(2): 1-15.

2. Ramalingam P, Subramaniyan V, Srinivasan P, Jobu GE, Morvin Y (2016) Quantitative traditional knowledge of medicinal plants used to treat livestock dieseases from Kudavasal taluk of Thiruvarur district, Tamil Nadu, India. Revista Brasileira de Farmacognosia 26(1): 109-121.

3. Jaijoy KS, Vannasiri P, Piyabhan NL, Boonraeng S (2010) Acute and subchronic toxicity study of the water extract forms the fruits of Piper chaba hunter in rats. International Journal of Applied Resource and Natural Product 3: 29-35.

4. Shivjeet S, Sandeep KS, Ashutosh Y (2013) Review on cassia species: pharmacological, traditional and medicinal aspects in various countries. American Journal of Phytomedicine and Clinical Therapeutics 1: 291312.

5. Byaruhanga C, Ndukui JN, Olinga S, Egayu G, Boma P, et al. (2015) Ethnoveterinary practices in the control of helminthosis and ticks of livestock amongst pastoralist in Karamoja Region, Uganda. Livestock Research for Rural Development 27(8): 21-32.

6. Talkmore N, Charlotte IEA, Joop TV, Jan HV (2015) Medicinal plants used by traditional healers for the treatment of malaria in the Chipinge district in Zimbabwe. Journal of Ethnopharmacology 159(15): 224-237.

7. Gobalakrishnan R, Kulandaivelu M, Bhuvaneswari R, Kandavel D, Kannan L (2013) Screening of wild plant species for antibacterial activity and phytochemical analysis of Tragia involucrate L. Journal of Pharmaceutical Analysis 3(6): 460-465.

8. Gesine P (2007) Artificial and bio-artificial liver support. Organogesis $3(1): 20-24$

9. Singh A, Bhat TK, Sharma OP (2011) Clinical Biochemistry of Hepatotoxicity. J Clinic Toxicol S4: 001.

10. Reitman S, Frankel S (1957) A colorimetric method for the determination of serum glutamic oxaloacetic and glutamic pyruvic transaminases. American J Clin Pathol 28(1): 56-63

11. Soares CF, Fonseca LM, Oliveira MC (2013) Application of Scharer's quantitative method for the determination of residual alkaline phosphatase activity in standard Minas. Arq Bras Med Vet Zootec 65(4).

12. Park GJ, Lin BP, Ngu MC, Jones DB, Katelaris PH (2000) Aspartate aminotransferase: alanine aminotransferase ratio in chronic hepatitis C infection: is it a useful predictor of cirrhosis. J Gastroenterol Hepatol 15(4): 386-390.

13. Caio MM, Cordova MN, De Cordova MM (2009) Interference on the laboratory measurement of bilirubin: the effect of in vitro interactions. Clinica Chimica acta 407(1-2):77-79.

14. Drury RA, Wallignton A, Cameroun SR (1967) Carleton's Histological Techniques. Oxford University Press, New York, USA.

15. Pratt J, Catherine W, Neil D, Brain M (2012) Advancing schizophrenia. Drug Discovery 11: 560-579.

16. Richard DB, Sudeepa B, Xi Y, Pritmohinder SG, Laura KS, et al. (2015) Translational biomarkers of acetaminophen-induced acute liver injury. Arch Toxicol 89(9): 1497-1522.

17. Brind AM (2007) Drugs that damage the liver. Medicine 35: 26-30.

18. Hirvinen M, Rajecki M, Parviainen S, Lagarstom RN, Diaconu I, et al. (2015) Immunological effects of a tumor necrosis factor alpha-armed oncolytic adenovirus. Human Gene Therapy 26(3):134-44.

19. Proskuryakov SY, Konoplyannikov AG, Gabai VL, Konoplyannikov AG, Gabai VL (2003) Necrosis: a specific form of programmed cell death? Exp Cell Res 283(1): 1-16.

20. Mohammed A, Mada SB, Yakasai HM (2012) Sub-chronic study of Aqueous Stem Bark Extract of Senna siamea in Rats. Asian J Biol Sci 5: 314-321.

21. Cosmas C, Giallourakis MD (2013) Liver Complications in Patients with Congestive Heart Failure. Gastroenterol Hepatol 9(4): 244-246. 
Creative Commons Attribution 4.0 International License

For possible submissions Click Here

Submit Article
Your subsequent submission with Crimson Publishers will attain the below benefits

- High-level peer review and editorial services

- Freely accessible online immediately upon publication

- Authors retain the copyright to their work

- Licensing it under a Creative Commons license

- Visibility through different online platforms

- Global attainment for your research

- Article availability in different formats (Pdf, E-pub, Full Text)

- Endless customer service

- Reasonable Membership services

- Reprints availability upon request

- One step article tracking system 